\title{
Conclusion to Part 3
}

[T] he deployment of Cuban armed forces controlled by Moscow [has] put a damper on American-Soviet Détente. Therefore, 1976 has a good chance of going down as the 'year of Africa' in the history of international politics. Consequently, in recent months, the Directorate of Political Affairs' activities focused [...] on Southern Africa. ${ }^{1}$

As Jürg Andreas Iselin, deputy director of the DPA and head of its African, Asian, Middle Eastern and Latin American Division, told his colleagues at the annual conference of Swiss ambassadors in September 1976, the shock of the Cuban invasion in Angola had focused Bern's attention on Africa. The victory of the Soviet-allied forces during the Angolan and Ogaden Wars increased the Swiss policymakers' loss of confidence in the capacity of the US to protect the interests of the Western bloc and undermined their belief in Détente. They also saw their commercial exchanges and investments on the African continent threatened as a consequence of the intensification of liberation struggles in Southern Africa after the MPLA victory in Angola and by the possibility of further Soviet-Cuban interventions in Africa. As a result, efforts were made within the Swiss federal administration to analyse the situation, take steps to prevent damage to Swiss interests, and consider ways to contribute to the containment of Soviet influence in Africa.

Although Switzerland's foreign policy was shaped more by the East-West conflict after the Angolan War, regional concerns continued to be decisive in its government's position during both the Angolan and Ogaden conflicts. The FPD publicly adopted an impartial attitude. However, the will to improve Switzerland's image and win the respect of African leaders, in order to safeguard economic interests in Southern Africa and on the continent as a whole, was the determining factor for Swiss foreign policy decisions. This is seen most clearly in the recognition of the PRA. Once FPD leaders realised that the MPLA was likely to win the Angolan War and that the OAU was considering recognising the PRA, concern about Switzerland's image in Southern Africa trumped apprehension about the MPLA's ideological orientation or a possibly negative US reaction. The weakened superpower was unable to prevent the almost

1 Emphasis in original. Presentation by Jürg Andreas Iselin, deputy chief of DPA and chief of its African, Asian, Middle Eastern and Latin American Division, held on 3 September 1976, "Die bilateralen Beziehungen der Schweiz zum Südlichen Afrika", appendix no 20 of the minutes of the Annual Conference of Swiss Ambassadors 1976, p. 3, SFA E2010-01A\#199o/5\#9*. 
universal recognition of the PRA in early 1976. In this context, the voices of Swiss business people who demanded recognition in order to create new economic opportunities strengthened a policy that was already set in motion.

While Swiss foreign policymakers did not hold back their criticism of American policy on Africa, they never questioned their own low-key role during the Angolan and Ogaden Wars. Although it is doubtful that the Swiss government could have made a positive contribution to mediation between the warring parties or easing East-West tensions, their pragmatic wait-and-see policy and, particularly, the early recognition of the PRA might be considered opportunistic. To defuse such criticism, Swiss diplomats employed a rhetoric of smallness and insisted on their position as a small European state with limited geopolitical influence. In addition, the ICRC relief missions in Angola and the Ogaden presented the Swiss government with an opportunity to show solidarity with the war's victims in a highly visible and, at the same time, ostensibly non-political way. In Angola, Bern's considerable financial and organisational support for the humanitarian organisation allowed it to benefit from the ICRC's high moral standing, earn the gratitude of all belligerents, and improve the image of Swiss neutrality. In the Ogaden, however, the ICRC's role was controversial. While there is no sign that Bern benefited politically from its association with the ICRC in Ethiopia and Somalia, its image did not suffer from it, either.

The years between 1975 and 1979 saw, both the culmination of the Swiss government's efforts to lead a more active foreign policy on the African continent, and the failure of these attempts. By the mid-197os, most FPD officials were convinced of the need to deepen Switzerland's relations with the Third World and to participate in the North-South dialogue. The victories of the Sovietbacked forces in Angola and the Ogaden added urgency to this. Yet, any real change in Switzerland's foreign policy in sub-Saharan Africa would have necessitated downgrading the country's economic and financial ties with South Africa. Against the background of a strong domestic lobby that prioritised relations with South Africa over those with the rest of the African continent, and a weakened Third World solidarity movement, the FPD's attempts to create a coherent Africa policy did not succeed. 